\title{
Measurement of Peasants' Satisfaction with the Compensation for Land Acquisition in the Chinese Mainland in the Last Thirty Years
}

\author{
Wang Xinliang \\ Department of Economic and Management, Zhejiang Water Conservancy and Hydropower College, \\ Hangzhou, China \\ Email: holdto@sina.com.cn
}

Received September $24^{\text {th }}, 2012$; revised October $26^{\text {th }}, 2012$; accepted November $3^{\text {rd }}, 2012$

\begin{abstract}
Based on theories and documents, initial quantization table of peasants' land acquisition compensation satisfaction has been developed. It consists of compensation standard, compensation procedure, compensation mode, and compensation distribution. Through on-spot interviews and pre-tested questionnaires, the final scale is determined. After the questionnaire surveys and primary component analysis, ultimately, we conclude that compensation degree, compensation procedure, and compensation mode are the main dimensions of the peasants' satisfaction with the compensation for land acquisition. This reliable operating tool makes up for the limits of situational specificity and shortcoming of recognition inconsistence of land acquisition compensation from the current bibliography, and promotes in-depth research and theorizations of land-acquisition compensation.
\end{abstract}

Keywords: Land Acquisition; Compensation Satisfaction; Compensation Degree; Compensation Procedure; Compensation Mode

\section{Introduction}

The essence of land acquisition is the redistribution of land property among the peasants whose lands are acquisitioned by the government. Other members of the village, land developers, and such local administrations, as village cadres, township and counties all tried their best to maximize their own benefits. In the existing property right and institutional framework, government's forcible land acquisition act does not protect famers' wish. This leads to endless disputes. Yu Jianrong 于建嵘 pointed out that rural land disputes had replaced tax disputes and currently become the main reason for peasants' rights protests, $\mathrm{Yu}$ observed that this was mainly because governmental acquisition of lands was practiced without peasants' permission, or the compensation was too low, or government embezzled the compensation.

In large number and often in passive situations, peasants, as a vulnerable group, are the main stakeholders of land. Obtaining the least interests, peasants become the most dissatisfied group. What are the specific elements of the peasants' satisfaction with land-acquisition compensation and what's the degree of the satisfaction?

\section{Theoretical Basis}

\section{The Compensation Satisfaction Theory}

Satisfaction has long been an important indicator of management science, especially in psychology research. Each generation of management masters has come up with their own theories and models.

F. W. Taylor "the father of scientific management" already established a prototype of the idea of satisfaction. Herzberg uses two-factor theory to further inquire which factors lead to job satisfaction and dissatisfaction.

P. C. Smith's (1969) Equity Model extends and expands the satisfaction theory. He thinks that people will compare the investment and reward ratio. If their investment and reward ratio are equal with others', they will feel fair. Conversely, if the self ratio is far behind others', they will feel unfair and unsatisfied. R. A. Ash (1965) points out that everyone has the output which is obtained from work and the input faith which is essential to achieve these outputs. These studies have laid a foundation for follow-up compensation satisfaction research.

\section{The Development of Compensation Satisfaction}

A number of researchers have deepened the satisfaction theory. The Lawler (1971) discrepancy model points out that people will compare the actual reward with what they should be paid, and the results will affect their pay satisfaction.

According to the Modified Discrepancy Model by Heneman and Schwab (1985) salary satisfaction should consist of four dimensions, namely, "salary", "pay and promotion", "salary policy and management", and "welfare". Their model has changed the view that salary satisfaction is a single surface structure. The first to discover the problem is Dreher (1988), who studied the salary and welfare satisfaction of "common guarantee scope and employee costs borne" with the sample of 1433 police officers. There were no specific differences ob-served among the officers, though they found that welfare actually had influence over welfare and salary satisfaction. Another forerunner is Henmeman (1988) who conducted researches on all the four satisfaction factors. Heneman (1988) examined the relationship between job performance compensa- 
tion and compensation satisfaction based on a research sample of 104 hospital staff. He found that there would be some differences using different survey methods, just the same as Drehe et al. had found. The third to find this problem is Miceli et al. (1991). Their study of the compensation system satisfaction (structure and management) features a sample of 2000 managers, who were divided into several levels according to their positions. The study found that the view on salary system fairness influenced organizational justice. External comparisons play an important role in determining satisfaction rather than salary system. At the same time, the study further notes that a high level executive force makes the salary system fairer.

A compensation satisfaction research review for the last 30 years finds two obvious phenomena. First, people almost always use the same satisfaction content and variables related to work. For example, Ronan and Organ (1973) investigated how work experience, age, education, gender, organizational capacity, and the actual wage influence salary satisfaction. At the same time, Rice et al. (1990) did the same research with almost the same variables. But there are also differences between their researches. For example, a study does not regard it as organization ability, but in another study it is often regarded as a part of the organization ability. And some of other same routine variables have been used for many years. Second, most of the studies only concentrate on the pay satisfaction, much to the negligence of raise, benefits, compensation system structure, and management satisfaction. But some researchers investigated some or all the four factors.

The satisfaction theory is not only applied in the field of human resource management, and government departments, but also in public administration, health, science and technology education.

\section{The Measurement of Compensation Satisfaction}

At the beginning, most methods measuring satisfaction adopted one-dimensional method-Minnesota satisfaction questionnaire (Minnesota Weiss et al., 1967) and job satisfaction index (Smith et al., 1967), Later on the main satisfaction model (Dyer \& Theriault, 1976; Lawler, 1971) came to be is multidimensional model.

Heneman (1985) believes that either the theory of compensation satisfaction or actual measurement of the compensation satisfaction can help researchers understand the causes and results of satisfaction. He and Schwab, developed and validated a multidimensional method which was used to measure satisfaction, namely pay satisfaction questionnaire (Pay Satisfaction Questionnaire, PSQ). Because of the satisfactory results, they turned to remuneration related subjects and methods to do conducted more research (Heneman \& Schwab, 1985). Some researchers have verified the correctness and reliability of the PSQ (Judge \& Wellbourne, 1994; Mulvey et al., 1991). But there is at least one non-western researcher that questioned the validity of these four factors (Lam, 1998). The study by Lam in Hong Kong illustrated that there are only two factors - salary and welfare - connected to the compensation satisfaction. Ever since, people went on with some more investigations. But most of the research is on the PSQ dimension (Ash et al., 1990; Chrraher, 1991; Buckley, 1996; Carraher et al., 2004; Carraher \& Scarpello, 1993; Mulvey et al., 1990; Orpen \& Bonnici, 1987; Lance \& Scarpello, 1989; Scarpello et al., 1988). As regards the differences between compensation satisfaction measurement and compensation satisfaction theoretical results, almost everyone predicts on the pay level while neglecting the factors that can influence satisfaction, such as salary, benefits and compensation management system and structure. P. Feuille (1974) found that after controlling distributive justice, the interpretation difference of distributive justice $(18.8 \%)$ on pay satisfaction is two times larger than procedural $(8.7 \%)$. Dreher (1981) shows that the relationship between distributive justice $(0.78)$ and salary satisfaction is greater than procedural justice $(0.42)$. Miceli et al. (2000) also come to the same conclusion. In his research on university instructors' satisfaction, Wu Xiaoyi 吴 小易 (2006) finds it obvious that justice in salary assessment procedure plays an important part in satisfaction effect. There have also been some empirical studies that have investigated the moderating variables and intermediary variable mechanism. Scarpello (1988) found that procedural justice was a conditioning variable through which fair distribution influences satisfaction behavior. Lawler (1971) found that fair distribution influenced organizational commitment through compensation, but procedural justice on salary satisfaction had no direct effect on it, and that procedural justice just influenced the organization commitment through satisfaction with supervisor. Smith (1969) points out that compensation level, compensation structure, and pay grade have a great effect on salary satisfaction, and there is positive relation between salary level and salary satisfaction. Derher (1981) also shows that the real wage and salary satisfaction among the correlation coefficient is 0.28 , but the proportion of wage growth and salary satisfaction among the correlation coefficient is 0.07 .

Initially the research of satisfaction or satisfaction measurement in the Chinese mainland is was focused on service Industry, such as the satisfaction change of bank service, the satisfaction in retail area of domestic and foreign brands, the tourism satisfaction in ecological tourism, rural tourism, ancient villages tourism, and so on. Later, their inquisition extended to the satisfaction with government service such as administrative services, public projects. In recent years, there are a lot of satisfaction researches related to peasants, including studies of peasant life, medical insurance, rural public goods, employment, and so on. Informed by foreign research, the research method used by the scholars gradually changes from quantitative research to qualitative research. In conclusion, in terms of approach methodology, variables, and measurement dimensions the present study acknowledges important inspiration from those research projects.

\section{The Conceptual Model and Research Hypothesis}

\section{Modeling}

The reason why peasants are not satisfied and why there are lots of disputes is summarized below and shown in Table 1.

The first is compensation standard. Of all the 44 documents related to land compensation issues, there are 36 (i.e. $81.8 \%$ ) based on compensation standard of land acquisition and regarding the low compensation standard as the main reason for the dissatisfaction of the peasants. Zhu Mingfen 朱明芬 (2003); Kong Xiangzhi 孔祥智, Wang Zhiqiang 王志强 (2004); Lu Qian 陆迁, Ye Xiaowen 叶小雯 (2005), Zhong Shuiying 钟 水映 (2007), Qian Zhonghao 钱忠好, Ma Kai 马凯 (2007), Zhao Wei 赵伟, Zhang Zhengfeng 张正峰 (2009), and Lin 
Table 1.

The main problems in land acquisition compensation.

\begin{tabular}{ccc}
\hline $\begin{array}{c}\text { The main problems which effect } \\
\text { land acquisition satisfaction }\end{array}$ & Quantities & Proportion \\
\hline Compensation standard & 36 & $81.8 \%$ \\
Compensation mode & 31 & $70.5 \%$ \\
Compensation distribution & 18 & $40.9 \%$ \\
Compensation procedure & 18 & $40.9 \%$ \\
The scope of compensation & 7 & $15.9 \%$ \\
The scope of land acquisition & 4 & $9.1 \%$ \\
Method of measurement & 4 & $9.1 \%$ \\
The ownership of the land & 3 & $6.8 \%$ \\
Total documents & 44 & \\
\hline
\end{tabular}

Qiling 林其玲 (2009) have all carried on the analysis in this regard. Therefore, the compensation standard for land acquisition was listed as one of the factors that affect peasants' land acquisition satisfaction.

The second is the compensation mode. $31 \%$ or $70.5 \%$ of the literature suggests that compensation mode affects the peasants' satisfaction. But the perspective research area is different, for it includes employment, social security, resettlement effect, single resettlement and settlement in wrong place and so on. This study also lists compensation mode as one of the influence factors.

The third is compensation distribution for land expropriation. There are 18 papers (about $40.9 \%$ of all) arguing that compensation distribution for land acquisition is an important fact affecting land expropriation. Three angles were analyzed in this part. The first one is the distribution of land value increment taken by An Husen 安虎森 and Zou Xuan 邹琁 (2005). The second is the amount of compensation collective internal distribution discussed by Lin Qiling 林其玲 (2009). The third one is an analysis of compensation for land acquisition (CLA henceforward) from the administrative decision of leaving and village committee retained.

The fourth and last one is compensation procedure. It is examined from quite dispersive angles in those papers, some of which focus on imperfect institution system, government monopoly, or government interference. They also investigated such other topics as illegal operations, management confusion, funds management, public participation, and so on. Although the contents are rich and diversified, the main ways are decision-making, behavior and supervision of CLA. There is no unified naming in this area. It is appropriate for Chen Zhen 陈 真 (2006), Zhao Wei 赵伟, Zhang Zhengfeng 张正峰 (2009) and others to present a summary using compensation procedure. We hence name it compensation procedure in our further analysis of it as an influencing factor. There are 7 articlessuch as those by Zhong Shuiying 钟水映 (2007), Yu Jianrong 于建嵘 (2008) - that consider CLA range as also an important factor which can affect the satisfaction. They analyze the compensation, operating losses and compensation rent losses, transfer fees, emotional compensation, and so on. There are 4 articles-including Zou Xuan's 邹琁 (2005) - that consider land acquisition measuring method as the main problem of
CLA And there are 4 articles exemplified by that by Zhao Wei 赵伟 and Zhang Zhegfeng 张正峰 (2009), in which the scopes of public purpose in land acquisition are identified to be the main factors that affect satisfaction factors. In general, the numbers of study in these three types are relatively small, which means that accredited degree is relatively low. At the same time, the author thinks that these three types are the factors affecting the low land compensation standard. Therefore, these three types are listed together and returned to the factors of compensation standard.

There are 3 authors, Liu Yue 刘乐 and Yang Xuecheng 杨 学成 (2009), Qin Hui 覃卉 (2006), Jin Shigao 金士高 (2006), who think that ownership is the main problem in CLA. It is the main cause of disorder of CLA distribution. Therefore, it doesn't become a separated influence factor.

In short, this study suggests that what affects peasants' CLA are compensation standard, compensation method, compensation distribution and compensation procedure.

In the following, Figure 1 diagrams the measurements of specific variables.

\section{The Research Hypotheses}

The following assumptions are made based on the understanding of related meaning and relevant model.

Hypothesis 1: CLA standard is an element of peasant compensation satisfaction dimensions;

Hypothesis 2: The CLA mode is an element of peasant compensation satisfaction dimensions;

Hypothesis 3: The land compensation distribution is an element of peasant compensation satisfaction dimensions;

Hypothesis 4: The CLA procedure is an element of peasant compensation satisfaction dimensions.

\section{Empirical Analysis}

\section{Questionnaire Form}

According to the research model, preliminary indexes with other related issues in peasants' CLA satisfaction were designed. To study the satisfaction of those with their land acquisitioned and to make questionnaire close to the reality, an almost month-long series of individual interview was organized from early October to early November in 2009. After the interview, four dimensions were determined to constitute compensation satisfaction. They are compensation standard, compensation method, compensation distribution, and compensation procedure The interview eliminates some unclear and incomprehensive questions in the questionnaire. Finally, we obtained the initial measured variables'.

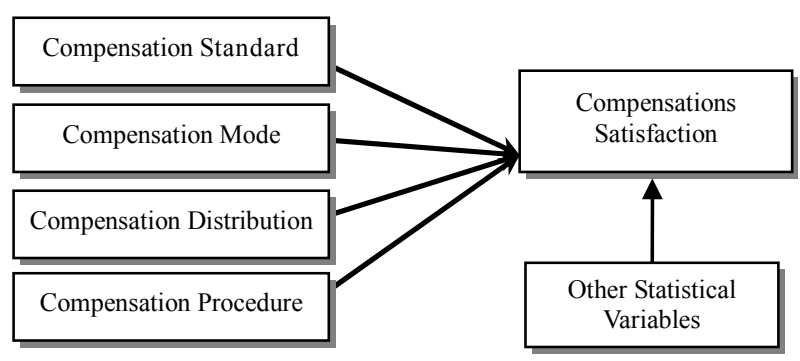

Figure 1.

Research model. 
1) The first level index. CLA satisfaction is the first level indicator.

2) The second level index. There are four second level indexes, namely CLA standard satisfaction, CLA mode satisfaction, land compensation distribution satisfaction, CLA procedure satisfaction.

3) The third level index. According to the literature research and interview, we select 25 indicators in level three.

4) The definition of measuring index. In the light of the third index, we defined the indicators.

Measurement index. Likerte symmetric five index scales were used to measure the third level indexes. In order to avoid the interference on the respondents from the answer sequence, half of the questionnaire options are 1 totally agree, 2 agree, 3 general, 4 do not quite agree, 5 totally disagree. While the other half options are 1 strongly disagree, 2 do not quite agree, 3 general, 4 quite agree, 5 totally agree. We change the reverse variable questions when we put the data into computer.

\section{Investigation Process}

The survey was completed during the Labor Day Holidays. The sample range is in accordance with the actual, the way of getting sample is scientific and strict. There are 350 questionnaires totally which are shown in Table 2 . There are only 10 investigation samples from Changshan and Daishan due to the small populations of the two counties. The other 22 counties each claim 15 samples. The number of the total recovered questionnaires is 261 , the effective recovery rate of which is $72.8 \%$.

\section{A Description of the Sample}

As shown in Table 3, males account for $80.8 \%$ and females account for $19.2 \%$. Males take a larger part in the survey. People of 30 years old or younger account for $9.2 \%$. People aged between 31 and 40 account for $23.1 \%$. Those between 41 and 50 years old account for $54.7 \%$. And those between 51 and 60 account for $9.8 \%$. People over 61 years old took up $3.2 \%$. The middle aged is the main part of the survey.

The education levels of the samples are as follows: primary school or below, 49.3\%; junior middle school, $26.2 \%$, senior mille school and secondary technical, $19.8 \%$, college degree or above, $4.6 \%$. There are three fourths of the samples educated below junior high school.

Families with one, two, three, four, and five or more mem-

Table 2.

Composition of samples.

\begin{tabular}{cccccc}
\hline Location & Number & Location & Number & Location & Number \\
\hline Haiyan & 9 & Yiwu & 11 & Huangyan & 12 \\
Pinghu & 10 & Dongyang & 14 & Linhai & 9 \\
Tongxiang & 13 & Lanxi & 11 & Cixi & 13 \\
Shangyu & 11 & Lishui & 9 & Anji & 10 \\
Shaoxing county & 11 & Jinyun & 12 & Yinzhou & 14 \\
Shengzhou & 13 & Wencheng & 12 & Ninghai & 12 \\
Xinchang & 9 & Pingyang & 13 & Changshan & 7 \\
Changxing & 12 & Jiangshan & 9 & Daishan & 5 \\
\hline
\end{tabular}

Table 3.

Sample survey.

\begin{tabular}{|c|c|c|}
\hline Category & Option & Proportion \\
\hline \multirow{2}{*}{ Sex } & Male & $80.8 \%$ \\
\hline & Female & $19.2 \%$ \\
\hline \multirow{5}{*}{ Age } & 30 years and below & $9.2 \%$ \\
\hline & $31-40$ years & $23.1 \%$ \\
\hline & $41-50$ years & $54.7 \%$ \\
\hline & $51-60$ years & $9.8 \%$ \\
\hline & 61 years and above & $3.2 \%$ \\
\hline \multirow{4}{*}{ The education level } & Primary school and below & $49.3 \%$ \\
\hline & Junior middle school & $26.2 \%$ \\
\hline & $\begin{array}{l}\text { Senior middle school and } \\
\text { secondary specialized school }\end{array}$ & $19.8 \%$ \\
\hline & Junior college and above & $4.6 \%$ \\
\hline \multirow{5}{*}{$\begin{array}{c}\text { The number of family } \\
\text { member }\end{array}$} & 1 & $1.9 \%$ \\
\hline & 2 & $12.0 \%$ \\
\hline & 3 & $30.9 \%$ \\
\hline & 4 & $39.1 \%$ \\
\hline & 5 and above & $16.1 \%$ \\
\hline \multirow{4}{*}{$\begin{array}{l}\text { The main source } \\
\text { of income }\end{array}$} & Agriculture & $30.6 \%$ \\
\hline & Working & $47.9 \%$ \\
\hline & Business & $11.4 \%$ \\
\hline & Others & $10.1 \%$ \\
\hline \multirow{2}{*}{$\begin{array}{l}\text { Presently registered } \\
\text { permanent residence }\end{array}$} & Rural residence & $81.4 \%$ \\
\hline & Non-rural residence & $18.6 \%$ \\
\hline
\end{tabular}

bers account for, respectively, $1.9 \%, 12 \%, 30.9 \%, 39.1 \%$, and $16.1 \%$, which means that families with three or four members constitute the largest part and take up more than $80 \%$.

Thirty point six per cent of the landless peasants have their main income from agriculture account for $30.6 \%, 47.9 \%$ working elsewhere, $11.4 \%$ doing business, $10.1 \%$ engaged in other trades. Because the agriculture is not as popular as it was in Zhejiang province, most of the peasants there have turned to sidelines.

In the investigation, $81.4 \%$ of the peasants are still registered as permanent rural residents, while $18.6 \%$ of them are not. Most peasants still retain a rural household. Among those peasants whose land was expropriated, only a small portion fully completed their transformation into nonagricultural residence.

\section{A Preliminary Assessment of Data Quality \\ The Validity of Questionnaire}

The exploratory factor analysis, KMO and Bartlett sphere of the questionnaire all meet the requirements, which are shown in Table 4.

Test "do you agree" by, After the KMO sampling and Bart- 
lett test of the 14 questions answered by 261 investigators, the result shows a KMO value of 0.729 and Bartlett test value of $1616.68(p<0.001)$, which reach significant level. These 14 entries can be factor analysis.

\section{Questionnaire Reliability Test}

Used in this paper, is the Cronbach's alpha coefficient that was put forward in 1951 by Cronbach. Table 5 shows that reliability coefficient is positively related to credibility of the measurements.

As seen in Table 5, besides the Cronbach's alpha coefficient for CLA program is 0.585 and the rest are bigger than 0.7 . Overall, this questionnaire reliability is acceptable.

\section{The Analysis of Exploratory Factor}

Table 6 shows a general dissatisfaction with the 14 variables among peasants in the questionnaire. The peasants are satisfied with the 14 describe problems in land acquisition process, but they are not satisfied with the CLA now. Of these 14 variables, the peasants speak highly of the following three variables, the average of lower living standard for land acquisition (3.0766); the average of life threaten for old-age pension, medical care and other social security problem which cannot be solved properly (3.0881); the average of land compensation fee that shall be enjoyed by members of the village land ownership (3.0077).

The peasants are most unsatisfied -3.4253 on average-with the resettlement arrangements that lack effective policy advocacy. Their dissatisfaction with the lack of powerful supervision of is also high, reaching 3.3946. There is also a high dissatisfaction (3.3831) of the large amount of retentate, diversion of land acquisition compensation and the non-standard use of capital and the little actual obtained capital of peasants. Factor analysis is a unity of two kinds of analysis, one of which is purely exploratory factor analysis. The aim of exploratory factor analysis (Exploratory Factor Analysis, EFA) is to identify the essential structure of the observed variables from a group of data and thereby develop a new hypothesis or theory frame

Table 4.

$\mathrm{KMO}$ and Bartlett test.

\begin{tabular}{|c|c|c|}
\hline \multicolumn{2}{|c|}{ Sampling enough metric of Kaiser-Meyer-Olkin } & 0.781 \\
\hline \multirow{3}{*}{ Bartlett Sphericity Test } & Approximate chi-squared & 1844.898 \\
\hline & df & 91 \\
\hline & Sig. & 0.000 \\
\hline
\end{tabular}

Table 5.

Reliability analysis.

\begin{tabular}{ccc}
\hline Test project & Question numbers & Cronbach's $\alpha$ coefficient \\
\hline $\begin{array}{c}\text { Land acquisition } \\
\text { compensation procedure }\end{array}$ & 4 & 0.856 \\
$\begin{array}{c}\text { Land acquisition } \\
\text { compensation distribution }\end{array}$ & 4 & 0.823 \\
$\begin{array}{c}\text { Land acquisition } \\
\text { compensation standard }\end{array}$ & 3 & 0.585 \\
$\begin{array}{c}\text { Land acquisition } \\
\text { compensation mode }\end{array}$ & 3 & 0.738 \\
\hline
\end{tabular}

capable of changing those variables with complicated and confused relations into a few common factors so as to describe variation of questions. Its idea is to simplify the complication.

This paper uses exploratory-factor analysis. It mainly includes Principal Component Analysis Methods, PCA, Varimax, and Factor Analysis. Among the quantity decision of the factors, those whose characteristic value (Eigenvalue) is greater than 1 are regarded as evaluation standard. The following three rules were observed during the screening variables measuring project (Item): 1) we deleted those factors with only one question for there are no internal consistency. 2) The load of the factors belonging to the question had to be greater than 0.5 and with convergent validity; otherwise it would be deleted. 3) The load of every corresponding question should be close to 1 .

The common factor is the concentrated extract of original index information, featuring clear explanatory factor to each original variable. And the original index can be expressed as a sum of common factors and special factors. Common factors do contribution to the quadratic sum of all load in the model. The contribution rate of the common factor equals to the proportion of corresponding feature values in the whole. Finally each research variable is decomposed into several affecting factor variables and is shown in Table 7.

This paper also uses the method of principal component analysis to solve the initial variance contribution rate, common factor characteristic value, and the cumulative variance contribution rate (see the table). According to the principal that characteristics of the male factor should be greater than 1 , three initial factors were determined. In Table 8, it can be seen from the Variance Column that the contribution of extracting 3 factors can reach $62.840 \%$, which shows that extracting 3 common factors can fully retain the variable information.

The initial factor loading matrix requires that the factors should have clear, reasonable and realistic meaning. Therefore, in order to better understand the factors of practical significance, this paper uses the Vrimax with Kaisr Normalization to rotate the factor. The load matrix of the rotation factor is shown in Table 9.

\section{Hypothesis Testing and Discussion}

Finally, Table $\mathbf{1 0}$ is based on the following 3 meaningful factors according to the factor loading matrix, namely land acquisition compensation procedure satisfaction, land acquisition compensation level of satisfaction, and land acquisition compensation model satisfaction.

Research shows that the peasants whose lands were acquisitioned are not satisfied with the compensation (only 3.2942 in all dimensions of variables). There are $0.4 \%$ who are very satisfied, $14.7 \%$ who are satisfied, $40.5 \%$ who feel just so-so, $36.6 \%$ who are not satisfied, and $7.5 \%$ who are not satisfied at all. The ones who are not satisfied and not satisfied account for $44.1 \%$. What the peasants care the most in the acquisite process is the benefits they will get. In this regard, the peasants' best wish is to have a high CLA benefits based on market value compensation. Huang Xianjin 黄贤金 (2003) argues that land acquisition costs should refer to the price on land market. While Zhang Runsen 张润森 (2009) thinks that peasants trade freely is just reasonable in theory.

What the peasants fear is that the CLA procedure is unfair and the CLA mode is improper, which will affect their final income. Therefore, peasants are also concerned about the said 
WANG X. L.

Table 6.

Descriptive statistics.

\begin{tabular}{|c|c|c|c|c|c|}
\hline & $\mathrm{N}$ & Minimum value & Maximum value & Average value & Standard deviation \\
\hline Lack of effective policy advocacy on land acquisition & 261 & 1.00 & 5.00 & 3.4253 & 0.77408 \\
\hline Almost no comments from peasants & 261 & 1.00 & 5.00 & 3.3870 & 0.85915 \\
\hline Lack of effective regulation on CLA & 261 & 2.00 & 5.00 & 3.3946 & 0.86013 \\
\hline Only very simple rules on CLA relief & 261 & 1.00 & 5.00 & 3.3602 & 0.85518 \\
\hline $\begin{array}{l}\text { The government got most profit by to buying the land at a } \\
\text { low price and selling it at high price, Peasants cannot } \\
\text { enjoy the benefits of land acquisition }\end{array}$ & 261 & 1.00 & 5.00 & 3.3180 & 0.94178 \\
\hline $\begin{array}{l}\text { The interception diversion of land acquisition money is } \\
\text { large and the its use is non-standard }\end{array}$ & 261 & 1.00 & 5.00 & 3.3831 & 0.99940 \\
\hline The actual income of peasants is too little & 261 & 1.00 & 5.00 & 3.3831 & 0.96414 \\
\hline $\begin{array}{l}\text { Land compensation money shall be owned by all the } \\
\text { village members }\end{array}$ & 261 & 1.00 & 5.00 & 3.0077 & 0.94865 \\
\hline $\begin{array}{l}\text { CLA is below the agricultural production value } \\
\text { before land acquisition }\end{array}$ & 261 & 1.00 & 5.00 & 3.3372 & 0.98514 \\
\hline There are different compensation standard in the region & 261 & 1.00 & 5.00 & 3.3602 & 0.96106 \\
\hline The living standard of the peasants before the acquisition & 261 & 1.00 & 5.00 & 3.0766 & 0.82850 \\
\hline $\begin{array}{l}\text { Land compensation fees will soon be spent out and } \\
\text { peasant will become poorer }\end{array}$ & 261 & 1.00 & 5.00 & 3.3257 & 0.77786 \\
\hline $\begin{array}{l}\text { Pension and medical protection is not properly resolved, } \\
\text { and peasant life is at more risk }\end{array}$ & 261 & 1.00 & 5.00 & 3.0881 & 0.86151 \\
\hline $\begin{array}{l}\text { Peasants have no long-term guarantee and they } \\
\text { will lose jobs again }\end{array}$ & 261 & 1.00 & 5.00 & 3.2720 & 0.76883 \\
\hline Effective N (list of state) & 261 & & & & \\
\hline
\end{tabular}

Table 7.

Common factor variance.

\begin{tabular}{|c|c|c|}
\hline & Initial & Extraction \\
\hline Lack of effective policy advocacy on land acquisition & 1.000 & 0.880 \\
\hline Almost no comments from peasants & 1.000 & 0.658 \\
\hline Lack of effective regulation on CLA & 1.000 & 0.650 \\
\hline Only very simple rules on CLA relief & 1.000 & 0.638 \\
\hline $\begin{array}{l}\text { The government got most profit by buying the land at a low price and selling it at high price, } \\
\text { Peasants cannot enjoy the benefits of land acquisition }\end{array}$ & 1.000 & 0.868 \\
\hline The interception diversion of land acquisition money is large and the its use is non-standard & 1.000 & 0.710 \\
\hline The actual income of peasants is too little & 1.000 & 0.719 \\
\hline Land compensation money shall be owned by all the village members & 1.000 & 0.248 \\
\hline CLA is below the agricultural production value before land acquisition & 1.000 & 0.407 \\
\hline There are different compensation standards in the region & 1.000 & 0.802 \\
\hline The living standard of the peasants before the acquisition & 1.000 & 0.212 \\
\hline Land compensation fees will soon be spent out and peasant will become poorer & 1.000 & 0.823 \\
\hline Pension and medical protection is not properly resolved, and peasant life is at more risk. & 1.000 & 0.509 \\
\hline Peasants have no long-term guarantee and they will lose jobs again & 1.000 & 0.675 \\
\hline Extraction method: principal component analysis & & \\
\hline
\end{tabular}


WANG X. L.

Table 8.

Total variance explained.

\begin{tabular}{|c|c|c|c|c|c|c|}
\hline \multirow{2}{*}{ Component } & \multicolumn{3}{|c|}{ Initial eigenvalues } & \multicolumn{3}{|c|}{ Extraction of square and loading } \\
\hline & Sum & Variance $\%$ & Cumulative $\%$ & Sum & Variance $\%$ & Cumulative $\%$ \\
\hline 1 & 4.098 & 29.269 & 29.269 & 4.098 & 29.269 & 29.269 \\
\hline 2 & 2.786 & 19.900 & 49.168 & 2.786 & 19.900 & 49.168 \\
\hline 3 & 1.914 & 13.672 & 62.840 & 1.914 & 13.672 & 62.840 \\
\hline 4 & 0.968 & 6.911 & 69.751 & & & \\
\hline 5 & 0.790 & 5.642 & 75.393 & & & \\
\hline 6 & 0.698 & 4.985 & 80.378 & & & \\
\hline 7 & 0.624 & 4.460 & 84.838 & & & \\
\hline 8 & 0.516 & 3.686 & 88.524 & & & \\
\hline 9 & 0.484 & 3.461 & 91.985 & & & \\
\hline 10 & 0.378 & 2.698 & 94.683 & & & \\
\hline 11 & 0.252 & 1.799 & 96.481 & & & \\
\hline 12 & 0.209 & 1.491 & 97.973 & & & \\
\hline 13 & 0.163 & 1.168 & 99.140 & & & \\
\hline 14 & 0.120 & 0.860 & 100.000 & & & \\
\hline Extraction meth & compo & & & & & \\
\hline
\end{tabular}

Table 9.

Component matrix.

\begin{tabular}{|c|c|c|c|}
\hline & \multicolumn{3}{|c|}{ Component } \\
\hline & 1 & 2 & 3 \\
\hline Lack of effective policy advocacy on land acquisition & 0.365 & 0.834 & 0.226 \\
\hline Almost no comments from peasants & 0.294 & 0.736 & 0.170 \\
\hline Lack of effective regulation on land acquisition compensation & 0.259 & 0.740 & 0.186 \\
\hline Only very simple rules on CLA relief & 0.371 & 0.680 & 0.196 \\
\hline $\begin{array}{l}\text { The government got most profit by buying the land at a low price and selling it at high price, } \\
\text { Peasants cannot enjoy the benefits of land acquisition }\end{array}$ & 0.891 & -0.267 & -0.041 \\
\hline The interception diversion of land acquisition money is large and its is non-standard & 0.817 & -0.203 & 0.038 \\
\hline The actual income of peasants is too little & 0.821 & -0.206 & 0.045 \\
\hline Land compensation money shall be owned by all the village members & 0.471 & -0.151 & 0.060 \\
\hline Land acquisition compensation is below the agricultural production value before land acquisition & 0.560 & -0.306 & -0.002 \\
\hline There are different compensation standard in the region & 0.853 & -0.271 & -0.003 \\
\hline The living standard of the peasants before the acquisition & 0.421 & -0.078 & 0.168 \\
\hline Land compensation fees will soon be spent out and peasant will become poorer & -0.236 & -0.223 & 0.847 \\
\hline Pension and medical protection is not properly resolved, and peasant life is at more risk. & -0.052 & -0.272 & 0.657 \\
\hline Peasants have no long-term guarantee and they will lose jobs again & -0.192 & -0.250 & 0.759 \\
\hline \multicolumn{4}{|l|}{ Extraction method: principal component analysis } \\
\hline a. Having extracted 3 ingredients & & & \\
\hline
\end{tabular}


Table 10.

Factor named.

\begin{tabular}{|c|c|}
\hline \multirow{4}{*}{$\begin{array}{c}\text { Land acquisition } \\
\text { compensation } \\
\text { procedure }\end{array}$} & Lack of effective policy advocacy on land acquisition \\
\hline & Almost no comments from peasants \\
\hline & Lack of effective regulation on CLA \\
\hline & Only very simple rules on CLA relief \\
\hline \multirow{5}{*}{$\begin{array}{l}\text { Land acquisition } \\
\text { compensation } \\
\text { standard }\end{array}$} & $\begin{array}{l}\text { The government got most profit by buying the land at a low price and selling it at high price, Peasants } \\
\text { cannot enjoy the benefits of land acquisition }\end{array}$ \\
\hline & The interception diversion of land acquisition money is large and its use is non-standard \\
\hline & The actual income of peasants is too little \\
\hline & Land acquisition compensation is below the agricultural production value before land acquisition \\
\hline & There are different compensation standard in the region \\
\hline \multirow{3}{*}{$\begin{array}{l}\text { Land acquisition } \\
\text { compensation mode }\end{array}$} & Land compensation fees will soon be spent out and peasant will become poorer。 \\
\hline & Pension and medical protection is not properly resolved, and peasant life is at more risk. \\
\hline & Peasants have no long-term guarantee and they will lose jobs again \\
\hline
\end{tabular}

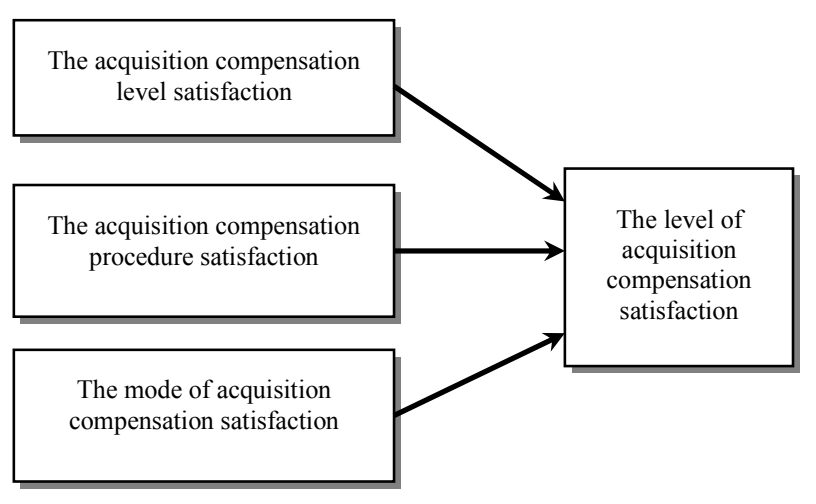

Figure 2.

CLA satisfaction.

procedure and mode. The results of the tested hypothesis are as follow:

Hypothesis 1: the compensation standard of CLA is not the dimension of peasant compensation satisfaction.

Hypothesis 2: the CLA mode is the dimension of peasant compensation satisfaction.

Hypothesis 3: the distribution of CLA is not the dimension of the peasant compensation satisfaction.

Hypothesis 4: CLA procedure is the dimension of peasants' compensation satisfaction.

\section{Conclusion}

By analyzing peasants' views, the present study has identified the most prominent factors which influence peasants' CLA satisfaction. CLA satisfaction consists of compensation standard, compensation procedure, compensation mode, and compensation distribution.

Through the literature review, a pretest questionnaire and then a scale questionnaire are used to collect data, which is tested to be valid and reliable.

After the principal component analysis and testing, we find that peasants' CLA satisfaction as shown in Figure 2, is com- posed of compensation level, compensation procedures and compensation model.

\section{REFERENCES}

Bos, W., \& Tarnai, C. (1999). Content analysis in empirical social research. International Journal of Educational Research, 31, 659-671.

Chen Zhen 陈真 (2006). Zhengdi buchang wenti zhengce fenxi ji zhengce xuanze 征地补偿问题政策分析及政策选择. Zhongguo Guotu Ziyuan Jingji, 10, 9-11.

Chen Shuwen 陈树文, \& Yu Muyao 于慕尧 (2008). Woguo shidi nongmin zhengdi buchang moshi yanjiu 我国失地农民征地补偿模 式研究. Dalian Ligong Daxue Xuebao (Shehui kexue ban), 4, 52-57.

Chen Jianglong 陈江龙, Qu Futian 曲福田, \& Chen Wen 陈雯 (2004). Nongdi feinonghua xiaolü de kongjian chayi ji qi dui tudi liyong zhengce tiaozheng de qishi 农地非农化效率的空间差异及其对土 地利用政策调整的启示. Guanli Shijie, 8, 37-42.

Coase (1994). The problem of social cost. Shanghai triple in 1994.

Dang Guoying 党国英 (2004). Guanyu zhengdi zhidu de sikao 关于征 地制度的思考. Xiandai Chengshi Yanjiu, 3, 19-22.

Fan Hui 范辉 (2008). Jiyu gengdi ziyuan jiazhi de zhengdi wanquan buchang wenti tanxi 基于耕地资源价值的征地完全补偿问题探析. Nongcun Jingji, 5, 35-38.

Huang Chaoming 黄朝明, Chen Jianwen 陈建文 et al. (2004). Shixi zhengdi guocheng zhongde zhuti liyi fenpei 试析征地过程中的主体 利益分配. Nongcun Jingji, 7, 21-24.

Huo Yaqin 霍雅勤, \& Cai Yunlong 蔡运龙 (2003). Kechixu linian xia de tudi jiazhi jueding yu lianghua 可持续理念下的土地价值决定与 量化. Zhongguo Tudi Kexue, 2, 19-23.

Jin Shigao 金士高 (2004). Tudi zhengyong buchang feiyong biaozhun de heli queding 土地征用补偿费用标准的合理确定. Zhejiang Guotu Ziyuan, 12, 19-22.

Jin Xiaobin 金晓斌 et al. (2008). Bei zhengdi nongmin liuyongdi anzhi moshi shiyongxing pingjia yanjiu-Fenxi Zhejiang sheng dianxing anli 被征地农民留用地安置模式适用性评价研究一一分析浙江省 典型案例. Zhongguo Tudi Kexue, 9.

Johnston, W. J., Leach, M. P., \& Liu, A. H. (1999). Theory testing using case studies in business-to-business research. Industrial Marketing Management, 28, 201-213.

doi:10.1016/S0019-8501(98)00040-6 
Kong Xiangzhi 孔祥智, \& Wang Zhiqiang 王志强 (2004). Woguo chengzhenhua jincheng zhong shidi nongmin de buchang 我国城镇 化进程中失地农民的补偿 Jingji Lilun yu Jingji Guanli, 5.

Kong Xiangzhi 孔祥智 (2007). Shidi nongmi "shouchang yiyuan" yingxiang yinsu de shizheng fenxi 失地农民“受偿意愿”影响因素的 实证分析. Shanxi Caijing Daxue Xuebao, 6.

Lei Shifeng 雷仕凤, \& Zhong shuiying 钟水映 (2005). Zhengdi buchang de kunjing yu duice 征地补偿的困境与对策. Zhongguo Gaige, 6.

Li Fanrong 李繁荣 (2006). Woguo zhengdi guocheng zhong de tudi shouyi fenpei zhidu fenxi 我国征地过程中的土地收益分配制度分 析. Shanxi Caijing Daxue Xuebao, 2.

Li Mingyue 李明月, \& Jiang Hua 江华 (2007). Shidi nongmin liudi anzhi fangshi yanjiu 失地农民留地安置方式研究. Jingji Tizhi Gaige, 2.

Li Mingyue李明月, \& Hu Zhuzhi 胡竹枝 (2008). Shidi nongmin anzhi yiyuan ji qi yingxiang yinsu: Guangzhou gean 失地农民安置意愿及 其影响因素: 广州个案. Gaige, 5.

Liu Yue 刘乐, \& Yang Xuecheng 杨学成 (2009). Kaifaqu shidi nongmin buchang anzhi ji shengcun zhuangkuang yanjiu-Yi Taian shi gaoxin jishu chanye kaifaqu weili 开发区失地农民补偿安置及 生存状况研究一一泰安市高新技术产业开发区为例. Zhongguo Tudi Kexue, 4.

Lin Qiling 林其玲 (2009). Woguo zhengdi buchang zhidu wenti fenxi 我国征地补偿制度问题分析. Nongcun Jingji Wenti, 10.

Liu Yaling 刘亚玲 (2005). Anzhao shichang jingji banfa queding zhengdi buchang biaozhun 按照市场经济办法确定征地补偿标准. Jingji Xuejia, 3.

Luo Yujie 罗玉洁, \& He Shanshan 何珊珊 (2009). Tudi zhengyong de shichanghua buchang moshi yanjiu 土地征用的市场化补偿模式研 究. Zhongguo Jingji Daokan, 16.

Lu Hongsheng 陆红生, \& Han Tongkui 韩桐魁 (2003). Guanyu tudi zhengyong zhidu gaige ruogan wenti de sikao 关于土地征用制度改 革若干问题的思考. Huazhong Nongye Daxue Xuebao (Shehui kexue ban), 1 .

Qian Zhonghao 钱忠好, \& Ma Kai 马凯 (2007). Woguo chengxiang feinongjianshe yongdi shichang: Longduan, fenge yu zhenghe 我国 城乡非农建设用地市场: 垄断、分割与整合. Guanli Shijie, 6.

Qin Hui 覃卉 (2006). Woguo tudi zhengshou chengxu de wanshan 我 国土地征收程序的完善. Gaige yu Zhanlue, 1 .

Ruan Xingwen 阮兴文 (2008). 构建征地补偿的正当程序规制. Kaifang Baodao, 1.

Schuster, C. (2004). A note on the interpretation of weighted kappa and its relations to other rater agreement statistics. Educational and Psychological Measurement, 64, 243-253. doi: $10.1177 / 0013164403260197$

Shen Shouyu 沈守愚 (2002). Tudi faxue tonglong 土地法学通论. Beijing: Zhongguo Dadi Chubanshe.

Wang Hui 汪晖, \& Huang Zuhui 黄祖辉 (2004). Gonggong liyi, zhengdi fanwei yu gongping buchang-Cong liangge tudi touji anli tanqi 公共利益、征地范围与公平补偿一从两个土地投机案例谈 起. Jingji Xue (Jikan), 4.

Wang Yibai 王亦白 (2006). Tudi quanshu zhengyi tiaochu jizhi xu jianquan 土地权属争议调处机制需健全. Zhongguo Tudi, 6.
Wang Mingxiang 王明祥 (2003). Zhengdi buchang anzhi xianzhuang ji gaijin tujing 征地补偿安置现状及改进途径. Zhongguo Tudi, 6.

Wang Shiquan 王世全 (2006). Tudi zhengyong zhong liyi fenpei qianxi 土地征用中利益分配浅析. Zhongguo Fangdichan, 10.

Wang Shiquan 王修达 (2008). Zhengdi buchang anzhi zhong de gua yu bujun 征地补偿安置中的寡与不均. Zhongguo Nongcun Jingji, 2.

Wang Weilin 王伟林, Huang Xianjin 黄贤金, \& Chen Zhigang 陈志刚 (2009). Fada diqu nonghu bei zhengdi yiyuan ji yingxiang yinsuJiyu Suzhou nonghu diaocha de shizheng yanjiu 发达地区农户被征 地意愿及其影响因素—基于苏州农户调查的实证研究. Zhongguo Tudi Kexue, 4.

Xiao Yi 肖屹, Qian Zhonghao 钱忠好, \& Qu Futian 曲福田 (2009). Nongmin tudi chanquan renzhi yu zhengdi zhidu gaige yanjiu—Jiyu Jiangsu, Jiangxi liangsheng 401 hu nongmin de diaocha yanjiu 农民 土地产权认知与征地制度改革研究一基于江苏、江西两省 401 户农民的调查研究. Jingji Tizhi Gaige, 2.

Wu Minglong 吴明隆 (2008). SPSS caozuo yu yingyong-Wenjuan tongji fenxi shiwu SPSS 操作与应用一一问卷统计分析实务. Taichung: Wunan Tushu Chuban Gongsi.

Yang Chunxi 杨春禧 (2005). Lun zhengdi chengxu gaige yu hexie shehui goujian 论征地程序改革与和谐社会构建. Shehui Kexue Yanjiu, 5.

Yin, R. K. (1994). Case study research: Design and method. New York: Sage Publications.

Yu Jianrong 于建嵘 (2008). Tudi ying zhenzheng chengwei tongmin de caichan 土地应真正成为农民的财产. Huazhong Shifan Daxue Xuebao (Renwen shehui kexue ban), 2.

Yu Miao 于沝, \& Wu Jianping 伍建平 (2006). Zhejiang Jiaxing “yi tudi huan baozhang” de jingyan ji qi fansi 浙江嘉兴“以土地换保障” 的经验及其反思. Zhongguo Nongye Daxue Xuebao (Shehui kexue ban), 2.

Zhang Xiaoling 张晓玲, Lu Hai yuan 卢海元, \& Mi Hong 米红 (2006). Bei zhengdi Nongmin pinkun fengxuan ji anzhi cuoshi yanjiu 被征地 农民贫困风险及安置措施研究. Zhongguo Tudi Kexue, 1.

Zhang Quanjing, 张全景, \& Wang Wanmao 王万茂 (2003). Woguo tudi zhengyong zhidu de lilun kaocha ji gaige sikao 我国土地征用制 度的理论考察及改革思考. Jingji Dili, 6 .

Zhang Shuhuan 张术环 (2005). Chanquan, nongdi chanquan, nongdi chanquan zhidu 产权、农地产权、农地产权制度. Xueshu Luntan, 3.

Zhang Xingbin 张兴斌, \& Qi En 齐恩 (2007). Pingzhengdi buchang biaozhun cunzai de wenti ji xiangying duice 平征地补偿标准存在的 问题及相应对策. Tianjin Shangxueyuan Xuebao, 4.

Zhong Shuiying 钟水映, \& Li Kui 李魁 (2008). Zhengdi anzhi manyidu shizheng fenxi 征地安置满意度实证分析. Zhongguo Tudi Кехuе, 6.

Zhou Qiren 周其仁 (2004). Nongdi chanquanyu zhengdi zhiduZhongguo chengshihua mianlin de zhongda xuanze 农地产权与征地 制度一一国城市化面临的重大选择. Jingji Xue (Jikan), 4.

Zhu Mingfen 朱明芬 (2003). Zhejiang shidi nongmin liyi baozhang xianzhuang diaocha ji duice 浙江失地农民利益保障现状调查及对 策. Zhongguo Nongcun Jingji, 3. 